\title{
Physiological effects of fibre-rich types of bread
}

\section{The effect of dietary fibre from bread on the mineral balance of young men}

\author{
BY W. VAN DOKKUM, ANNEKE WESSTRA \\ AND FRANCIEN A. SCHIPPERS \\ Department of Nutrition, Institute CIVO-Toxicology and Nutrition-TNO, PO Box 360, \\ 3700 AJ Zeist, The Netherlands
}

(Received 5 June 1981-Accepted 14 December 1981)

\begin{abstract}
1. Twelve young adult male volunteers were given a low-fibre white bread diet $(9 \mathrm{~g}$ neutral-detergent fibre (NDF)/d) and a medium-fibre coarse-bran bread diet $(22 \mathrm{~g} \mathrm{NDF} / \mathrm{d}$ ), each lasting $20 \mathrm{~d}$. In a third period of $20 \mathrm{~d}$ the volunteers were subdivided in groups of four, consuming a high-fibre coarse-bran bread diet (35 $\mathrm{g} \mathrm{NDF} / \mathrm{d}$ ), a medium-fibre fine-bran bread diet (22 $\mathrm{g} \mathrm{NDF} / \mathrm{d}$, bran particle size $<0.35 \mathrm{~mm}$ ) or a wholemeal bread diet $(22 \mathrm{~g}$ $\mathrm{NDF} / \mathrm{d}$ ). Retention of calcium, magnesium, iron, zinc and copper were determined during each $20 \mathrm{~d}$ period.

2. An increase of the amount of dietary fibre (through bran in bread) from $9 \mathrm{~g}$ to $22 \mathrm{~g} \mathrm{NDF} / \mathrm{d}$ resulted in a significantly increased mineral intake, but also faecal excretion increased significantly; mineral retention remained almost constant.

3. Both intake and faecal excretion of all minerals studied, except faecal $\mathrm{Ca}$, increased further $(P<0.05)$ on the diet providing $35 \mathrm{~g} \mathrm{NDF} / \mathrm{d}$; only Fe balance decreased significantly. No significant differences with respect to intake, excretion (except urinary $\mathrm{Ca}$ ) and balance of the minerals could be detected between the coarse-bran bread and fine-bran bread diets providing $22 \mathrm{~g} \mathrm{NDF} / \mathrm{d}$. Faecal Fe, Cu balance and $\mathrm{Mg}$ balance increased significantly during the wholemeal bread period compared to the coarse-bran bread diet providing $22 \mathrm{~g} \mathrm{NDF}$.

4. Serum cholesterol increased significantly, i.e. by $0.3 \mathrm{mmol} / 1$, during the coarse-bran bread diet providing $22 \mathrm{~g}$ NDF, compared to the white-bread diet.

5. It is concluded that increasing the amount of bran in bread does not appear to affect mineral balance considerably but there seems to be an influence on mineral availability. The increased intake was accompanied by increased faecal excretion.
\end{abstract}

There is an increasing interest in the interaction of dietary fibre and minerals in the gastrointestinal tract. Some authors have already reported that dietary fibre might lower the availability of minerals which may lead to decreased absorption (Reinhold et al. 1976; Ismail-Beigi et al. 1977; Cummings, 1978; Sandstead et al. 1978; Drews et al. 1979; Kelsay et al. 1979). Dietary fibre is suggested to be effective in preventing the incidence of several diseases (Burkitt et al. 1974; Trowell, 1976); specifically the role of dietary fibre from cereal sources on colonic function seems to be of importance (Kelsay, 1978; Spiller et al. 1978). Since bread is one of the staple foods in many industrialized countries, the generally recommended increase of dietary fibre consumption might well be reached through fibre-rich bread. However, an over-estimation of the value of dietary fibre could lead to an excessive intake, which may have a negative influence on the mineral status owing to the possibly inhibitory effect of dietary fibre on mineral absorption.

As part of a larger project concerning the significance of bread in human nutrition, we have studied the consequences for human physiology of an increased intake of fibre from bread. The criteria studied included the colonic function, the digestibility of dietary fibre (components) by the intestinal microflora and the balance of calcium, magnesium, iron, zinc and copper. The results of the mineral balances are reported in this paper.

\section{METHODS}

The experimental design is shown in Table 1 . Twelve male volunteers (mean age $23 \pm 2$ years, weight $68 \pm 6 \mathrm{~kg}$, height $1.82 \pm 0.06 \mathrm{~m}$ and $14 \pm 3 \%$ body fat) were given two experimental 
Table 1. Experimental design*

\begin{tabular}{|c|c|c|c|c|c|}
\hline $\begin{array}{l}\text { Period... } \\
\text { Duration (d)... }\end{array}$ & $\begin{array}{c}\text { General adaptation } \\
\text { A } \\
8\end{array}$ & $\begin{array}{l}\text { First experimental } \\
\text { period } \\
\text { B } \\
20\end{array}$ & $\begin{array}{c}\text { Second experimental } \\
\text { period } \\
\text { C } \\
20\end{array}$ & & $\begin{array}{l}\text { Third experimental } \\
\text { period } \\
\text { D } \\
20\end{array}$ \\
\hline Type of bread & $\begin{array}{l}\text { White bread (entirely } \\
\text { white flour) }\end{array}$ & $\begin{array}{l}\text { White bread (entirely } \\
\text { white flour) }\end{array}$ & $\begin{array}{l}\text { Bread made from } \\
850 \mathrm{~g} \text { white flour } \\
\text { and } 150 \mathrm{~g} \text { coarse } \\
\text { bran } / \mathrm{kg}\end{array}$ & 1 & $\begin{array}{l}\text { Bread made from } \\
680 \mathrm{~g} \text { white flour } \\
\text { and } 320 \mathrm{~g} \text { coarse } \\
\text { bran } / \mathrm{kg}(n 4) \\
\text { Bread made from } 850 \mathrm{~g} \\
\text { white flour and } 150 \mathrm{~g} \\
\text { fine bran } / \mathrm{kg}(n 4) \\
\text { Wholemeal bread }(n 4)\end{array}$ \\
\hline $\begin{array}{l}\text { Approximate total } \\
\text { daily fibre } \\
\text { intake (g NDF) }\end{array}$ & 9 & 9 & 22 & & $\begin{array}{ll}1 & 35 \\
2 & 22 \\
3 & 22\end{array}$ \\
\hline
\end{tabular}

NDF, neutral-detergent fibre (Van Soest \& Wine, 1967).

* The study was carried out with four volunteers at a time and replicated twice (with other subjects), resulting in three experiments with four volunteers each. Only the last periods of $20 \mathrm{~d}$ were different.

diets with different amounts and types of dietary fibre for $20 \mathrm{~d}$ each. Results were compared with those on a low-fibre (white bread) diet with $9 \mathrm{~g}$ dietary fibre/d.

\section{Experimental procedure}

All volunteers consumed the white-bread diet (periods A and B) and the $150 \mathrm{~g}$ coarse-bran $/ \mathrm{kg}$ bread diet (period C). The amount of dietary fibre in the latter type of bread was the same as that in conventional wholemeal bread; the organoleptic properties were different however. In the third experimental period (period D), three other types of bread were consumed, each type by four of the twelve volunteers. The $150 \mathrm{~g}$ fine-bran $/ \mathrm{kg}$ bread was included to study the effect of the bran particle size on e.g. mineral balance. The $320 \mathrm{~g}$ coarse-bran $/ \mathrm{kg}$ bread contained twice the amount of dietary fibre as compared to conventional wholemeal bread, which was included as well. The particle size of the coarse and fine bran were $>0.35 \mathrm{~mm}$ and $<0.35 \mathrm{~mm}$ respectively.

The volunteers gave informed written consent according to the Institute's procedures and were housed in the Institute's controlled metabolic ward, but they continued their normal daily routines. They passed beforehand a clinical examination and a nutritional evaluation. The routine haematological values were all within normal ranges. The basal diet, which was constant throughout the study, consisted of conventional low-fibre foods and provided $7 \mathrm{~g}$ $\mathrm{NDF} / \mathrm{d}$ (see Table 2). The diet characteristics, based on analyses of individual duplicate daily samples, are given in Table 3 .

In practice an increased bran consumption automatically results in a higher mineral intake. The objective being to study the mineral availability under these conditions, no supplementation of minerals (e.g. in the white-bread period) was applied.

The energy intake was adjusted to the individual energy requirements based on a constant body-weight during the study and a dietary history before the experiment. Reduction of body-weight by more than $2 \%$ was corrected for by sugar, soft drinks and other carbohydrate equivalents. This procedure was necessary for four volunteers.

The food was prepared in the diet kitchen according to standard procedures, weighed to the nearest $\mathbf{g}$, packed in individual portions and deep-frozen when necessary.

Only demineralized water was allowed in restricted amounts (maximum approximately $200 \mathrm{ml}$ daily, apart from water for coffee and tea). All types of bread were prepared from 
Table 2. Composition $(g)$ of the basal diet

(Mean daily values)

\begin{tabular}{lrlr}
\hline \hline & & & \\
Bread* & 240 & Ground beef & 100 \\
Cheese & 60 & Ice cream & 50 \\
Smoked beef & 15 & Whipped cream & 25 \\
Ham & 15 & Vegetables & \\
Orange juice & 250 & Instant tea & $0 \cdot 9$ \\
Vegetable margarine & 30 & Instant coffee & 3 \\
Custard (low-fat) & 150 & Sugar & 20 \\
& 30 & Soft drinks & 400 \\
& 200 & Whisky & 35 \\
\hline
\end{tabular}

* Various types; for details, see Table 1.

$\dagger$ Each $4 \mathrm{~d}$ the following rotating order: day $1: 75 \mathrm{~g}$ string beans, 5 g-margarine, $100 \mathrm{~g}$ apple sauce; day 2 : $30 \mathrm{~g}$ lettuce, $40 \mathrm{~g}$ carrot salad, $40 \mathrm{~g}$ celeriac salad; day 3: $75 \mathrm{~g}$ sliced beans, $5 \mathrm{~g}$ margarine, $100 \mathrm{~g}$ apple sauce; day 4: $200 \mathrm{~g}$ tomatoes, $5 \mathrm{~g}$ margarine, $5 \mathrm{~g}$ rusk.

one batch of wheat flour. All meals were served at the Institute. The basal diet and the breads were analysed separately.

Urine samples $(24 \mathrm{~h})$ were collected in polyethylene bottles with hydrochloric acid as preservative. Stools were collected in 31 plastic buckets, one for every $4 \mathrm{~d}$, stored at $4^{\circ}$. Composites (4 d) of urine and stools were made for analysis and stored at $-20^{\circ}$.

Blood was withdrawn from the antecubital vein before breakfast at the beginning and at the end of each period.

\section{Analytical procedures}

The analytical procedures included mineral determinations by means of atomic absorption spectrophotometry (Perkin-Elmer 303). As wheat bran dietary fibre is low in water soluble components and in addition the basal diet (without bread) was low in dietary fibre, neutral-detergent fibre analyses were carried out according to the Van Soest method (Van Soest \& Wine, 1967), as an approximation for dietary fibre, applying predigestion with pancreatin to remove residual starch (Terry \& Outen, 1973). Blood haemoglobin levels were determined with the cyanmethaemoglobin method; for packed cell volume the micromethod was used; erythrocyte count by a Coulter counter; serum cholesterol was determined by means of the Huang method (Huang et al. 1961); serum triglycerides, enzymically, with the Eggstein (1968) method. For serum $\mathrm{Mg}, \mathrm{Zn}$ and $\mathrm{Cu}$, atomic absorption spectrophotometry was applied, serum Fe determination was carried out according to the Führ (1965) method and serum Ca with a Ca titrator (Raman \& Chang, 1974).

Mineral balance was calculated from $20 \mathrm{~d}$ dietary intake and urinary + faecal excretion in each experimental period (subdivided in five $4 \mathrm{~d}$ periods). For statistical evaluation the results of each dietary treatment were compared with the preceding treatment by means of analysis of variance (Snedecor \& Cochran, 1967), using Student's $t$ test for paired observations. The means for period D (four subjects) were compared with those of the corresponding subjects in period $\mathrm{C}$.

This research was approved from an ethical standpoint by a working group responsible for human nutrition studies.

\section{RESULTS}

The mineral balance data are presented in Tables 4-7.

An increased cereal-fibre intake (through bran in bread) resulted in statistically significantly $(P<0.01)$ increased intake of all minerals studied, as shown by the values of the $150 \mathrm{~g}$ coarse-bran $/ \mathrm{kg}$ bread period (period C) and those of the white-bread period (period B). 


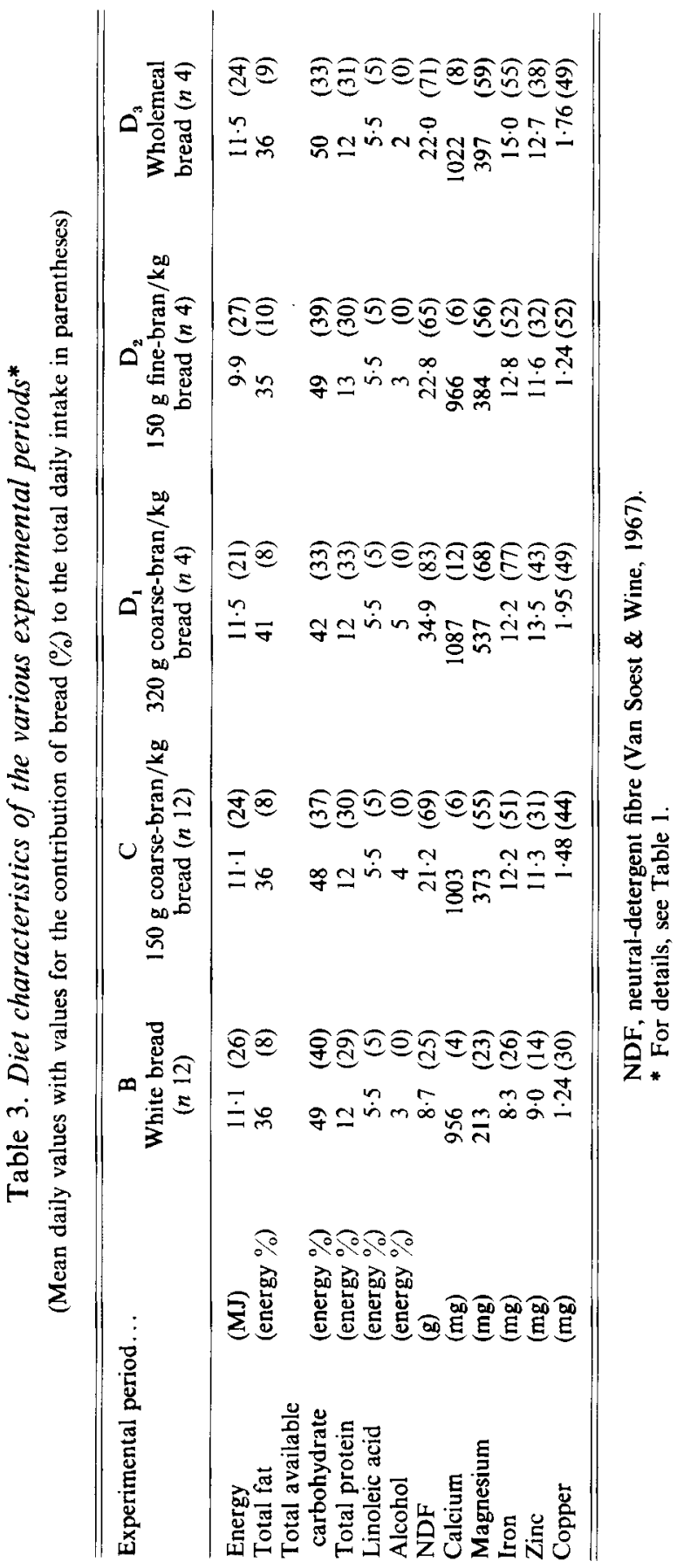


Table 4. Intake, excretion and balance of calcium, magnesium, iron, zinc and copper $(\mathrm{mg} / \mathrm{d})$ of human subjects on a white-bread diet and a $150 \mathrm{~g}$ coarse-bran $/ \mathrm{kg}$ bread diet during $20 \mathrm{~d}$

(Mean values and standard deviations)

\begin{tabular}{|c|c|c|c|c|}
\hline \multirow[t]{2}{*}{$\begin{array}{l}\text { Experimental period... } \\
\text { Type of bread... } \\
\text { NDF intake }(g / d) \ldots\end{array}$} & \multicolumn{2}{|c|}{$\begin{array}{c}\text { B }(n 12) \\
\text { White bread } \\
9\end{array}$} & \multicolumn{2}{|c|}{$\begin{array}{c}\mathrm{C}(n 12) \\
150 \mathrm{~g} \text { coarse-bran } / \mathrm{kg} \text { bread } \\
22\end{array}$} \\
\hline & Mean & $\mathrm{SD}$ & Mean & SD \\
\hline \multicolumn{5}{|l|}{$\mathrm{Ca}$} \\
\hline Intake & 956 & 40 & 1003 & $90^{*}$ \\
\hline Urinary & 225 & 79 & 209 & 90 \\
\hline Faecal & 717 & 99 & 836 & $99^{*}$ \\
\hline Balance & 14 & 118 & -42 & 109 \\
\hline \multicolumn{5}{|l|}{$\mathbf{M g}$} \\
\hline Intake & 213 & 13 & 373 & $15^{*}$ \\
\hline Urinary & 116 & 8 & 136 & $14^{*}$ \\
\hline Faecal & 105 & 16 & 240 & $24^{*}$ \\
\hline Balance & -8 & 15 & -3 & 22 \\
\hline \multicolumn{5}{|l|}{$\mathrm{Fe}$} \\
\hline Intake & $8 \cdot 3$ & 0.6 & $12 \cdot 2$ & $0.5^{*}$ \\
\hline Urinary & $0 \cdot 1$ & 0.05 & 0.1 & 0.02 \\
\hline Faecal & $7 \cdot 4$ & $1 \cdot 1$ & 11.4 & $0.9^{*}$ \\
\hline Balance & 0.8 & $1 \cdot 2$ & 0.7 & 0.7 \\
\hline \multicolumn{5}{|l|}{$\mathrm{Zn}$} \\
\hline Intake & $9 \cdot 0$ & $0 \cdot 2$ & $11 \cdot 3$ & $0.2^{*}$ \\
\hline Urinary & 0.7 & $0 \cdot 3$ & 0.6 & $0 \cdot 3$ \\
\hline Faecal & 8.9 & $1 \cdot 5$ & $11 \cdot 1$ & $0.9 *$ \\
\hline Balance & -0.6 & 1.7 & -0.4 & 1.0 \\
\hline \multicolumn{5}{|l|}{$\mathrm{Cu}$} \\
\hline Intake & $1 \cdot 24$ & 0.23 & 1.48 & $0.19^{*}$ \\
\hline Urinary & 0.05 & 0.01 & 0.05 & 0.01 \\
\hline Faecal & 0.97 & $0 \cdot 16$ & $1 \cdot 18$ & $0 \cdot 11^{*}$ \\
\hline Balance & 0.22 & 0.29 & 0.25 & 0.24 \\
\hline
\end{tabular}

NDF, neutral-detergent fibre (Van Soest \& Wine, 1967).

Mean values significantly different from those for period B : $* P<0.01$.

This change in the type of bread consumed also resulted in significantly $(P<0.01)$ increased faecal mineral excretion; urinary excretion of $\mathrm{Ca}, \mathrm{Fe}, \mathrm{Zn}$ and $\mathrm{Cu}$ remained constant $(\dot{P}>0.05)$, whereas urinary $\mathrm{Mg}$ excretion increased significantly $(P<0.01)$ during the $150 \mathrm{~g}$ coarse-bran $/ \mathrm{kg}$ bread period; no significant differences in any of the mineral balance values could be detected however.

During the $320 \mathrm{~g}$ coarse-bran $/ \mathrm{kg}$ bread period (period $\mathrm{D}_{1}$, see Table 5) all mineral intakes were higher when compared with the $150 \mathrm{~g}$ coarse-bran $/ \mathrm{kg}$ bread period; except for $\mathrm{Ca}$, faecal mineral excretion increased significantly $(P<0.05)$ as well, whereas urinary mineral output did not change significantly. As to the mineral balance values, only Fe balance decreased significantly $(P<0.01)$ during period $\mathrm{D}_{1}$. However, except for $\mathrm{Cu}$, all mineral balance values were negative in the $320 \mathrm{~g}$ coarse-bran $/ \mathrm{kg}$ bread period.

Apart from a significant decrease $(P<0.01)$ in urinary Ca in period $\mathrm{D}_{2}(150 \mathrm{~g}$ fine-bran $/ \mathrm{kg}$ bread) as compared with period $C(150 \mathrm{~g}$ coarse-bran $/ \mathrm{kg}$ bread), intakes of all minerals as well as excretion in urine and faeces were not changed significantly (see Table 6). Although all mineral balance values seem to have improved on the fine-bran bread diet, none of the differences compared with the $150 \mathrm{~g}$ coarse-bran $/ \mathrm{kg}$ bread diet was statistically significant. 
Table 5. Intake, excretion and balance of calcium, magnesium, iron, zinc and copper $(\mathrm{mg} / \mathrm{d})$ of four human subjects on a $150 \mathrm{~g}$ coarse-bran $/ \mathrm{kg}$ bread diet and a $320 \mathrm{~g}$ coarse-bran $/ \mathrm{kg}$ bread diet during $20 d$

(Mean values and standard deviations)

\begin{tabular}{|c|c|c|c|c|}
\hline \multirow[t]{2}{*}{$\begin{array}{l}\text { Experimental period... } \\
\text { Type of bread ... } \\
\text { NDF intake }(g / d) \ldots\end{array}$} & \multicolumn{2}{|c|}{$\begin{array}{c}\mathrm{C}(n \mathrm{n}) \\
150 \mathrm{~g} \text { coarse-bran } / \mathrm{kg} \text { bread } \\
22\end{array}$} & \multicolumn{2}{|c|}{$\begin{array}{c}\mathrm{D}_{1}(n 4) \\
320 \mathrm{~g} \text { coarse-bran } / \mathrm{kg} \text { bread } \\
35\end{array}$} \\
\hline & Mean & SD & Mean & SD \\
\hline \multicolumn{5}{|l|}{$\mathrm{Ca}$} \\
\hline Intake & 1019 & 30 & 1087 & $30^{* *}$ \\
\hline Urinary & 224 & 53 & 211 & 43 \\
\hline Faecal & 816 & 155 & 906 & 98 \\
\hline Balance & -21 & 123 & -30 & 42 \\
\hline \multicolumn{5}{|l|}{$\mathrm{Mg}$} \\
\hline Intake & 377 & 8 & 537 & $8^{* *}$ \\
\hline Urinary & 128 & 12 & 130 & 9 \\
\hline Faecal & 234 & 12 & 410 & $22^{* *}$ \\
\hline Balance & 15 & 16 & -3 & 14 \\
\hline \multicolumn{5}{|l|}{$\mathrm{Fe}$} \\
\hline Intake & $11 \cdot 8$ & 0.6 & $12 \cdot 2$ & $0 \cdot 6^{* *}$ \\
\hline Urinary & $0 \cdot 1$ & 0.02 & $0 \cdot 1$ & 0.03 \\
\hline Faecal & $10 \cdot 5$ & 0.6 & $15 \cdot 0$ & $0-8^{* *}$ \\
\hline Balance & $1 \cdot 2$ & 0.9 & $-2 \cdot 9$ & $0 \cdot 4^{* *}$ \\
\hline \multicolumn{5}{|l|}{$\mathrm{Zn}$} \\
\hline Intake & $11 \cdot 2$ & 0.2 & $13 \cdot 5$ & $0 \cdot 2^{* *}$ \\
\hline Urinary & 0.5 & $0 \cdot 2$ & 0.5 & $0-2$ \\
\hline Faecal & $10 \cdot 8$ & $1 \cdot 3$ & $13 \cdot 6$ & $0.9^{*}$ \\
\hline Balance & $-0 \cdot 1$ & $1 \cdot 6$ & -0.6 & 0.8 \\
\hline \multicolumn{5}{|l|}{$\mathrm{Cu}$} \\
\hline Intake & $1 \cdot 64$ & 0.06 & 1.95 & $0.06^{* *}$ \\
\hline Urinary & 0.05 & 0.01 & 0.05 & 0.01 \\
\hline Faecal & $1 \cdot 11$ & 0.11 & 1.41 & $0 \cdot 10^{*}$ \\
\hline Balance & 0.48 & 0.17 & 0.49 & $0 \cdot 12$ \\
\hline
\end{tabular}

NDF, neutral-detergent fibre (Van Soest \& Wine, 1967).

Mean values significantly different from those for period $\mathrm{C}$ : ${ }^{*} P<0.05,{ }^{* *} P<0.01$.

During the wholemeal-bread period $\left(\mathrm{D}_{3}\right)$ all mineral intakes, except the $\mathrm{Ca}$ intake, were significantly higher than those during the $150 \mathrm{~g}$ coarse-bran $/ \mathrm{kg}$ bread period (see Table 7); a significant increase in faecal $\mathrm{Fe}$ excretion $(P<0.01)$ could be detected whereas faecal excretions of the other minerals and all urinary mineral excretions did not differ significantly from the $150 \mathrm{~g}$ coarse-bran $/ \mathrm{kg}$ period. The balance values of $\mathrm{Ca}, \mathrm{Zn}$ and Fe were also similar in both periods; $\mathrm{Cu}$ balance and $\mathrm{Mg}$ balance however, increased significantly $(P<0.05)$ during the wholemeal-bread period.

Table 8 shows the results in blood serum obtained at the beginning and at the end of the $20 \mathrm{~d}$ experimental periods $\mathrm{B}$ and $\mathrm{C}$.

Small, but significant increases $(P<0.05)$ in haemoglobin levels, packed cell volume and the erythrocyte count were observed during the white-bread period. The mineral concentrations in blood serum appeared to be constant in most instances; though small differences were found, none reached statistical significance.

A significant increase of serum cholesterol $(P<0.05)$ during the $150 \mathrm{~g}$ coarse-bran $/ \mathrm{kg}$ 
Table 6. Intake, excretion and balance of calcium, magnesium, iron, zinc and copper $(\mathrm{mg} / \mathrm{d})$ of four human subjects on a $150 \mathrm{~g}$ coarse $\dagger-\mathrm{bran} / \mathrm{kg}$ bread diet and a $150 \mathrm{~g}$ fine $\dagger-\mathrm{bran} / \mathrm{kg}$ bread diet during $20 \mathrm{~d}$

(Mean values and standard deviations)

\begin{tabular}{|c|c|c|c|c|}
\hline \multirow[t]{2}{*}{$\begin{array}{l}\text { Experimental period... } \\
\text { Type of bread... } \\
\text { NDF intake }(\mathrm{g} / \mathrm{d}) . .\end{array}$} & \multicolumn{2}{|c|}{$\begin{array}{c}\mathrm{C}(n 4) \\
150 \mathrm{~g} \text { coarse-bran } / \mathrm{kg} \text { bread } \\
22\end{array}$} & \multicolumn{2}{|c|}{$\begin{array}{c}\mathrm{D}_{2}(n 4) \\
150 \mathrm{~g} \text { fine-bran } / \mathrm{kg} \text { bread } \\
22\end{array}$} \\
\hline & Mean & SD & Mean & SD \\
\hline \multicolumn{5}{|l|}{$\mathrm{Ca}$} \\
\hline Intake & 964 & 25 & 966 & 25 \\
\hline Urinary & 130 & 30 & 160 & $22^{*}$ \\
\hline Faecal & 841 & 40 & 758 & 91 \\
\hline Balance & -7 & 57 & 48 & 94 \\
\hline \multicolumn{5}{|l|}{$\mathrm{Mg}$} \\
\hline Intake & 374 & 15 & 384 & 15 \\
\hline Urinary & 130 & 13 & 134 & 10 \\
\hline Faecal & 247 & 29 & 240 & 37 \\
\hline Balance & -3 & 16 & 10 & 22 \\
\hline \multicolumn{5}{|l|}{$\mathrm{Fe}$} \\
\hline Intake & $12 \cdot 4$ & 0.3 & $12 \cdot 8$ & 0.3 \\
\hline Urinary & 0.1 & 0.02 & $0 \cdot 1$ & 0.02 \\
\hline Faecal & $12 \cdot 1$ & 0.2 & $11 \cdot 4$ & 0.8 \\
\hline Balance & $0 \cdot 2$ & $0 \cdot 3$ & $1 \cdot 3$ & 0.8 \\
\hline \multicolumn{5}{|l|}{$\mathrm{Zn}$} \\
\hline Intake & 11.4 & 0.2 & $11 \cdot 6$ & 0.2 \\
\hline Urinary & 0.6 & 0.2 & 0.6 & $0 \cdot 1$ \\
\hline Faecal & $11 \cdot 5$ & $0 \cdot 2$ & $10 \cdot 8$ & 0.8 \\
\hline Balance & -0.7 & $0 \cdot 3$ & 0.2 & $1 \cdot 0$ \\
\hline \multicolumn{5}{|l|}{$\mathrm{Cu}$} \\
\hline Intake & $1 \cdot 24$ & 0.04 & $1 \cdot 24$ & 0.04 \\
\hline Urinary & 0.05 & 0.01 & 0.05 & 0.01 \\
\hline Faecal & $1 \cdot 21$ & 0.05 & $1 \cdot 11$ & $0 \cdot 11$ \\
\hline Balance & -0.02 & 0.04 & 0.08 & 0.07 \\
\hline
\end{tabular}

NDF, neutral-detergent fibre (Van Soest \& Wine, 1967).

Mean values significantly different from those for period $C: * P<0.01$.

† Coarse-bran, particle size $>0.35 \mathrm{~mm}$, fine-bran, particle size $<0.35 \mathrm{~mm}$.

bread period (compared with the white-bread period) was observed. During the periods D none of the measured parameters in blood were statistically different from the corresponding periods $\mathrm{C}$ (results not presented).

\section{DISCUSSION}

McCance \& Widdowson (1942) suggested a possible relation between the type of bread consumed and mineral retention or absorption. The availability for absorption of minerals from wholemeal bread was considered to be less than that from white bread. The first explanation of an impaired mineral retention following the consumption of the darker types of bread seemed to be the presence of phytates which might make divalent electrolytes unavailable for absorption by the formation of insoluble complexes. Reinhold et al. (1976) and Ismail-Beigi et al. (1977) came to the conclusion that particularly dietary fibre from 
Table 7. Intake, excretion and balance of calcium, magnesium, iron, zinc and copper ( $\mathrm{mg} / \mathrm{d})$ of four human subjects on a $150 \mathrm{~g}$ coarse-bran $/ \mathrm{kg}$ bread diet and a wholemeal bread diet during $20 \mathrm{~d}$

(Mean values and standard deviations)

\begin{tabular}{|c|c|c|c|c|}
\hline \multirow[t]{2}{*}{$\begin{array}{l}\text { Experimental period... } \\
\text { Type of bread... } \\
\text { NDF intake }(\mathrm{g} / \mathrm{d}) \ldots\end{array}$} & \multicolumn{2}{|c|}{$\begin{array}{c}\mathrm{C}(n 4) \\
150 \mathrm{~g} \text { coarse-bran } / \mathrm{kg} \text { bread } \\
22\end{array}$} & \multicolumn{2}{|c|}{$\begin{array}{c}\mathrm{D}_{3}(n \quad 4) \\
\text { wholemeal bread } \\
22\end{array}$} \\
\hline & Mean & SD & Mean & $S D$ \\
\hline \multicolumn{5}{|l|}{$\mathrm{Ca}$} \\
\hline Intake & 1033 & 170 & 1022 & 114 \\
\hline Urinary & 273 & 110 & 203 & 40 \\
\hline Faecal & 850 & 97 & 829 & 91 \\
\hline Balance & -90 & 141 & -10 & 64 \\
\hline \multicolumn{5}{|l|}{$\mathrm{Mg}$} \\
\hline Intake & 369 & 21 & 397 & $23^{*}$ \\
\hline Urinary & 151 & 3 & 145 & 16 \\
\hline Faecal & 238 & 30 & 240 & 32 \\
\hline Balance & -20 & 19 & 12 & $12^{*}$ \\
\hline \multicolumn{5}{|l|}{$\mathrm{Fe}$} \\
\hline Intake & $12 \cdot 6$ & 0.2 & 15.0 & $0.9^{* *}$ \\
\hline Urinary & 0.1 & 0.02 & 0.1 & 0.02 \\
\hline Faecal & 11.6 & 0.9 & $12 \cdot 7$ & $0.9^{* * *}$ \\
\hline Balance & 0.9 & 0.7 & $2 \cdot 2$ & 0.2 \\
\hline \multicolumn{5}{|l|}{$\mathrm{Zn}$} \\
\hline Intake & $11 \cdot 2$ & 0.2 & $12 \cdot 7$ & $0.4^{* *}$ \\
\hline Urinary & 0.8 & 0.3 & 0.7 & $0 \cdot 3$ \\
\hline Faecal & $10 \cdot 9$ & 0.8 & $11 \cdot 4$ & 0.4 \\
\hline Balance & -0.5 & 0.9 & $0 \cdot 6$ & 0.3 \\
\hline \multicolumn{5}{|l|}{$\mathrm{Cu}$} \\
\hline Intake & 1.54 & 0.12 & 1.76 & $0 \cdot 12^{*}$ \\
\hline Urinary & 0.05 & 0.01 & 0.05 & 0.01 \\
\hline Faecal & $1 \cdot 21$ & $0 \cdot 14$ & 1.29 & $0 \cdot 12$ \\
\hline Balance & 0.28 & $0 \cdot 18$ & 0.42 & $0 \cdot 16^{*}$ \\
\hline
\end{tabular}

NDF, neutral-detergent fibre (Van Soest \& Wine, 1967).

Mean values significantly different from those for period $\mathrm{C}:{ }^{*} P<0.05, \quad{ }^{* *} P<0.01$.

bread could have an inhibitory effect on mineral absorption, possibly by mechanisms adsorbing the minerals to fibre. The presence of the enzyme phytase (EC 3.1.3.8) during the baking process of bread and in the intestinal tract of man might however increase the availability of the minerals by splitting the phytate-mineral complexes. A decreased mineral balance as a result of a more Western type of diet was also reported by Sandstead $e t$ al. (1978). Our results did not indicate an apparent influence on the mineral balance when the dietary fibre content was increased from $9 \mathrm{~g} \mathrm{NDF} / \mathrm{d}$ (white-bread diet) to $22 \mathrm{~g} \mathrm{NDF} / \mathrm{d}$ (bread with $150 \mathrm{~g}$ coarse-bran). The increased amount of minerals, which accompany the increased amount of bran (and thus of dietary fibre) did not appear to be available for absorption since faecal excretions of the minerals studied also increased. The significantly decreased Fe balance during period $\mathrm{D}_{1}$ with $35 \mathrm{~g} \mathrm{NDF} / \mathrm{d}$, together with the negative balance values for $\mathrm{Ca}, \mathrm{Mg}, \mathrm{Fe}$ and $\mathrm{Zn}$ as well as the significant further increase of faecal mineral excretions (except for $\mathrm{Ca}$ ), not only shows the influene of dietary fibre on mineral absorption, but also indicates that by increasing the quantity of bran in bread, the mineral utilization becomes less favourable. 
Table 8. Blood constituents values and serum biochemical criteria of human subjects on a white-bread diet and a $150 \mathrm{~g}$ coarse-bran $/ \mathrm{kg}$ bread diet during $20 \mathrm{~d}$

(Mean values and standard deviations)

\begin{tabular}{|c|c|c|c|c|c|c|}
\hline \multirow[t]{2}{*}{$\begin{array}{l}\text { Experimental period } \uparrow . . \\
\text { Type of bread... } \\
\text { NDF intake }(g / d) \ldots\end{array}$} & \multicolumn{2}{|c|}{$\begin{array}{c}\text { A }(n 12) \\
\text { White bread } \\
9\end{array}$} & \multicolumn{2}{|c|}{$\begin{array}{c}\text { B }(n 12) \\
\text { White bread } \\
9\end{array}$} & \multicolumn{2}{|c|}{$\begin{array}{c}\mathrm{C}(n 12) \\
150 \mathrm{~g} \text { coarse-bran } / \mathrm{kg} \text { bread } \\
22\end{array}$} \\
\hline & Mean & SD & Mean & SD & Mean & SD \\
\hline Haemoglobin $\quad(\mathrm{mmol} / \mathrm{l})$ & $9 \cdot 3$ & 0.4 & $9 \cdot 6$ & $0 \cdot 4^{*}$ & $9 \cdot 8$ & 0.5 \\
\hline Packed cell volume & 0.45 & 0.02 & 0.46 & $0.02 *$ & 0.47 & 0.02 \\
\hline Erythrocyte count $\left(10^{12} / 1\right)$ & $4 \cdot 6$ & $0 \cdot 3$ & $4 \cdot 8$ & $0 \cdot 3^{*}$ & $4 \cdot 7$ & 0.4 \\
\hline Serum Iron $\quad(\mu \mathrm{mol} / 1)$ & 21 & 6 & 17 & 4 & 18 & 6 \\
\hline Calcium $(\mathrm{mmol} / \mathrm{l})$ & $2 \cdot 40$ & $0 \cdot 10$ & $2 \cdot 45$ & 0.07 & $2 \cdot 45$ & 0.09 \\
\hline Magnesium (mmol/1) & 0.95 & $0 \cdot 14$ & 0.91 & $0 \cdot 12$ & 0.85 & $0 \cdot 14$ \\
\hline Zinc $\quad(\mu \mathrm{mol} / 1)$ & 16.8 & $4 \cdot 6$ & $15 \cdot 3$ & $6 \cdot 1$ & $18 \cdot 4$ & $3 \cdot 1$ \\
\hline$(\mu \mathrm{mol} / \mathrm{l})$ & $17 \cdot 3$ & $6 \cdot 3$ & $17 \cdot 3$ & $4 \cdot 7$ & $15 \cdot 7$ & 4.7 \\
\hline Total cholesterol & $4 \cdot 6$ & $1 \cdot 0$ & $4 \cdot 5$ & 0.6 & $4 \cdot 8$ & $0.8^{* *}$ \\
\hline Triglycerides & 1.33 & 0.53 & $1 \cdot 30$ & 0.54 & $1 \cdot 27$ & 0.44 \\
\hline
\end{tabular}

\footnotetext{
NDF, neutral-detergent fibre (Van Soest \& Wine, 1967).

$\dagger$ Blood was withdrawn at the end of each period indicated; for details, see Table 1.

Mean values significantly different from those for period $A:{ }^{*} P<0.05$.

Mean value significantly different from that for period $\mathrm{B}:{ }^{*} P<0 \cdot 05$.
}

No apparent influence of the bran particle size on mineral retention could be demonstrated, although the increased balance values during the fine-bran bread period indicate some effect; however, the inter-individual variations for the balance values were such that the mean differences were not statistically significant. During the wholemeal-bread period the dietary fibre intake was the same as during the $150 \mathrm{~g}$ coarse-bran $/ \mathrm{kg}$ bread period. The significant increase of the $\mathrm{Cu}$ and $\mathrm{Mg}$ balances could possibly be explained by the higher intakes during the wholemeal-bread period as excretion of both minerals remained almost constant.

For an explanation of the effects observed, we have to distinguish between: (1) the availability of the minerals for absorption and (2) the actual absorption step. The mineral balance (retention) is dependent on both availability and absorption.

Dietary fibre does not only seem to reduce the availability of minerals but we might also assume that the absorptive capacity of the intestinal wall is limited: excessive amounts cannot be absorbed. In other words, the intestinal wall only absorbs such amounts of minerals to maintain homoeostasis, which seems to be indicated by a rather constant urinary output. Finally, one should not underestimate the interactions of the minerals themselves when accounting for the findings observed, both during the digestion step (competition as to the availability) and during the actual absorption step (competition as to the transport mechanisms through the intestinal wall) (Davies, 1974).

Whether the suggested decreased mineral availability (whatever the cause may be) is a real problem in the Western type of diet is not easy to indicate. It is not impossible that in the long-term a physiological adaptation of the body to the increased consumption of dietary fibre (from bread) will occur, until, in a new equilibrium the absorption of the minerals will meet the requirements (Anderson et al. 1980). Besides, the risk of an impaired mineral absorption seems to be higher in countries where phytate-rich bread is consumed and where the daily diet is less varied as compared to the possibilities in the Western World. The negative balance for $\mathrm{Ca}, \mathrm{Mg}, \mathrm{Fe}$ and $\mathrm{Zn}$ in period $\mathrm{D}_{1}$ in which the amount of bran consumed is high, however, is an indication that even on a Western type of diet a too high 
wheat-fibre intake bears the risk of insufficient mineral absorption due to decreased availibility. No effects of alterations in the wheat-fibre intake on the mineral concentrations in blood serum of our subjects were observed, although it is questionable whether any changes are to be expected within $20 \mathrm{~d}$.

Increased serum cholesterol levels on a high wheat-fibre intake (through bran in bread) were also reported by other authors (Jenkins et al. 1975; Kay \& Truswell, 1977; Stasse-Wolthuis et al. 1980). Some investigators did not find elevated levels (Heaton \& Pomare, 1974; Dixon, 1978; Van Berge-Henegouwen et al. 1979). However, one may wonder whether the increase of serum cholesterol will be of any significance in a mixed diet with fruit and vegetables (in our study only low-fibre vegetables and no fresh fruit were consumed) since dietary fibre from fruit and vegetables (pectins) have been reported to decrease serum cholesterol levels (Grande et al. 1974; Stasse-Wolthuis et al. 1980).

\section{REFERENCES}

Anderson, J. W., Ferguson, S. K., Karounos, D., O’Malley, L., Sieling, B. \& Lin Chen, W. J. (1980). Diabetes Care 3, 38.

Burkitt, D. P., Walker, A. R. P. \& Painter, N. S. (1974). J. Am. med. Ass. 229, 1068.

Cummings, J. H. (1978). Am. J. clin. Nutr. 31, 21.

Davies, N. T. (1974). Proc. Nutr. Soc. 33, 293.

Dixon, M. (1978). Br. med. J. i, 578.

Drews, L. M., Kies, C. \& Fox, H. M. (1979). Am. J. clin. Nutr. 32, 1893.

Eggstein, M. (1968). Klin. Wschr. 44, 267.

Führ, J. (1965). Medsche. Mschr., N.Y. 19, 281.

Grande, F., Anderson, J. T. \& Keys, A. (1974). Am. J. clin. Nutr. 27, 1043

Heaton, K. W. \& Pomare, E. W. (1974). Lancet i, 49.

Huang, T. C., Chen, C. P., Wefler, V. \& Raftery, A. (1961). Analyt. Chem. 33, 1405.

Ismail-Beigi, F., Reinhold, J. G., Faraji, B. \& Abadi, B. (1977). J. Nutr. 107, 510.

Jenkins, D. J. A., Hill, M. S. \& Cummings, J. H. (1975). Am. J. clin. Nutr. 28, 1408.

Kay, R. M. \& Truswell, A. S. (1977). Br. J. Nutr. 37, 227.

Kelsay, J. L. (1978). Am. J. clin. Nutr. 31, 142.

Kelsay, J. L., Behall, K. M. \& Prather, E. S. (1979). Am. J. clin. Nutr. 32, 1876.

McCance, R. A. \& Widdowson, E. M. (1942). J. Physiol., Lond. 101, 44.

Raman, A. \& Chang, Y. K. (1974). Clin. Biochem. 7, 106.

Reinhold, J. G., Faradji, B., Abadi, B. \& Ismail-Beigi, F. (1976). J. Nutr. 106, 493.

Sandstead, H. H., Munoz, J. M., Jacob, R. A., Klevay, L. M., Reck, S. J., Logan, G. M., Dintzis, F. R., Inglett, G. E. \& Shuey, W. C. (1978). Am. J. clin. Nutr. 31, 180.

Snedecor, G. W. \& Cochran, W. G. (1967). Statistical Methods, 6th ed. Ames, Iowa: State University Press.

Spiller, G. A., Shipley, E. A. \& Blake, J. A. (1978). Crit. Rev. Fd. Sci. Nutr, 10, 31.

Stasse-Wolthuis, M., Albers, H. F. F., van Jeveren, J. G. C., de Jong, J. W., Hautvast, J. G. A. J., Hermus, R. J. J., Katan, M. B., Brydon, W. G. \& Eastwood, M. A. (1980). Am. J. clin. Nutr. 33, 1745.

Terry, R. A. \& Outen, G. E. (1973). Chem. Ind. 23, 116.

Trowell, H. (1976). Am. J. clin. Nutr. 29, 417.

Van Berge-Henegouwen, G. P., Huybregts, A. W., van de Werf, S., Demacker, P. \& Schade, R. W. (1979). Am. J. clin. Nutr. 32, 794.

Van Soest, P. J. \& Wine, R. H. (1967). J. Ass. Off. Analyt. Chem. 50, 50. 